\title{
Hydric and Edaphic Influence on Floristic Composition in an Altered Riparian Area
}

\author{
Diego Balestrin ${ }^{1}$ (D), Rafael Cruz ${ }^{2}$ (D), Geraldo Silveira² (D), \\ Sebastião Venâncio Martins ${ }^{1}$ \\ ${ }^{1}$ Laboratório de Restauração Florestal - LARF, Departamento de Engenharia Florestal, Universidade Federal de \\ Viçosa - UFV, Viçosa/MG, Brasil \\ ${ }^{2}$ Departamento de Engenharia Ambiental, Universidade Federal de Santa Maria - UFSM, Santa Maria/RS, Brasil
}

\begin{abstract}
Alteration of a natural ecosystem can physically, chemically and biologically affect a determined area. Therefore, this study aimed to evaluate the relation between the hydrology, soils and vegetation existing in an area changed by the implantation of a Hydroeletric Power Plant (HPP) in the municipality of Roque Gonzales, Rio Grande do Sul state. The study area was composed of three samples located downstream of the dam. This analysis was performed by the points method to verify the existence of similarity patterns between the vegetation, inundation levels and edaphic soil characteristics of each sample. As a result, greater floristic similarity was observed between the species as a relation of the spatial location with inundation levels. Thus, we can conclude that the vegetal establishment in the study area is under the direct influence of waterflow variation levels from the HPP, which contributes to defining species adaptability to these specific conditions, among others.
\end{abstract}

Keywords: environmental impacts, hydroelectric power plant, altered flow, riparian vegetation. 


\section{INTRODUCTION}

Alteration in a hydrological regime caused by the installation of a dam generates (among other problems) social impacts, flooding of areas, formation of a reduced flow section (RFS) downstream of the work and impacts existing vegetation. Due to the fact that these areas present a lower flow rate than what is observed prior to establishing the work and the consequent reduction of existing flood spikes prior to implementing the project, a portion of distinct vegetation is formed with differentiated variability and proportion from the preexisting normal vegetation (New \& Xie, 2008; Dwivedi, 2016; Bejarano et al., 2018), as well as differentiated soil characteristics (Stromberg, 2001; Silveira, 2006; Pereira et al., 2012).

Additionally (as discussed by Quadt et al., 2016), these altered areas can facilitate the entry of invasive species and compromise the diversity and integrity of the system, and should therefore be monitored and evaluated over time. In addition to these effects, fragmentation and terrestrialization tendencies can occur, as presented by Fanelli et al. (2015), as well as erosion and sedimentation in the area (New \& Xie, 2008).

In this sense, the physical conditions of the environment play a key role in structuring communities in lotic environments. This is confirmed by Schneck \& Hepp (2010) and Staes et al. (2010) who showed that the particular combination of several environmental factors such as current velocity, depth, bed substrate type, available light, organic matter and nutrients can determine the community that is associated with each habitat in a given watercourse.

Due to the fact that ciliary formations are connected to both the terrestrial and aquatic communities in an environment, they are influenced by both ecosystems. Thus, different types of soil are found in these areas, varying according to a greater or lesser degree of hydromorphism and the nature of the original material (Dalanesi et al., 2004; Curcio et al., 2007; Jacomine, 2009), as well as vegetation that is adapted to these conditions.

According to studies by Gonçalves et al. (2011), variations in fertility, soil acidity and altimetric elevation along a topographic gradient influence tree vegetation distribution; therefore, these characteristics directly influence the formation of local vegetation, its size, structure and floristic composition. Thus, the study of variations that occur in these particular environments is essential, since they have a direct relation with the local flora and fauna, influencing and reflecting any changes that may occur in these areas (Ivanauskas et al., 1997; Lima et al., 2003; Kotchetkoff-Henriques et al., 2005; Carvalho et al., 2009).

In this context, this study is justified by the need of determining and evaluating the adaptation of the riparian vegetation to the altered environments, as well as the influence that these anthropic alterations cause in the environment, more specifically on the established and directly influenced vegetation. Therefore, the main objective of this study was to understand the variation and distribution of vegetation along a stretch of area altered by the implantation of a Hydroelectric Plant and its relation with inundation levels and soil edaphic characteristics. Hence, this study searched patterns in the vegetation establishment according to the existing edaphic variation for each inundation level, as well as possible similarities between the areas; thus confirming the influence of flow peaks (moisture) on forming and defining the vegetation established therein.

The importance of this evaluation is directly related to minimizing the environmental impacts generated by implementing an enterprise. It also supports the definition of possible measures to accelerate the restoration process of altered ciliary environments through selecting better-adapted species to the conditions observed there.

\section{MATERIALS AND METHODS}

The study area is located at the Passo do São João HPP, located on the Ijuí river, more specifically in the municipality of Roque Gonzales, Rio Grande do Sul state, $28^{\circ} 07^{\prime} 51^{\prime \prime}$ latitude to the south and $55^{\circ} 01^{\prime} 33^{\prime \prime}$ longitude, being part of the Ijuí river in the Northwest region of the state. The reservoir also covers the municipalities of São Luiz Gonzaga, São Pedro do Butiá and Rolador (Silveira, 2006), approximately $600 \mathrm{~km}$ from Porto Alegre (RS)

According to Streck et al. (2008), the region's soil is mainly classified in areas of agriculture, fields and forests. According to the Köppen classification system, the region presents a hot and humid temperate climate (Cfa) in all seasons, presenting hot summers. Regarding 
precipitation in the region, data from 1988 to 2002 showed an annual average of $2210 \mathrm{~mm}$, distributed throughout the year and with greater intensity in the months of March and April, September and October (Unijuí, 2003).

The Passo São João HPP is part of a cascade system in the Ijuí river, preceded by the São José HPP in the municipality of Cerro Largo. It is a waterborne power plant, meaning that its reservoir only has the function of maintaining the necessary slope for generating energy (Silveira, 2006).

With its implementation in 2010, a RFS of approximately $4 \mathrm{~km}$ in length was formed between the dam and the powerhouse with lower flow regime, where its flow regime flows in accordance with the requirements established in the licensing process of the enterprise. In this river section with altered flow, three sample areas $(\mathrm{S} 1, \mathrm{~S} 2, \mathrm{~S} 3)$ were inserted to evaluate the vegetative and edaphic dynamics at different locations and flow characteristics (Figure 1).

Prior to the implantation of the hydroelectric plant, a varied range of ciliary vegetation along the canal formed this area, with agricultural influence and a gradual slope embankment. The exception was sample area 1, which presented an abrupt slope in its altimetric levels with greater flow influence by the river due to the direct influence of the HPP, with the flow speed and the embankment eroded by water action.

The process of locating the sample areas, defining the flood levels and consequently the vegetation analysis lines on the slope were based on the flow data provided by Eletrosul from September 2011 to December 2013 The channel bathymetry through the ADCP (Acoustic Doppler Current Profiler) was used to calculate the flow in real time with a consequent adjustment using the daily flow data from 1958 to 2008 through the 75320000 fluviometric station, which is to say in the pre-establishment period of the dam.

This information was correlated through an evaluation of the key curve for the daily pre-dam flow data, adding the post-dam flow information and actual flows in the sample areas, thus defining the flood levels for each sample. This adjustment was made possible by the formula in Equation 1 (adapted from Silveira et al. 2010), as follows:

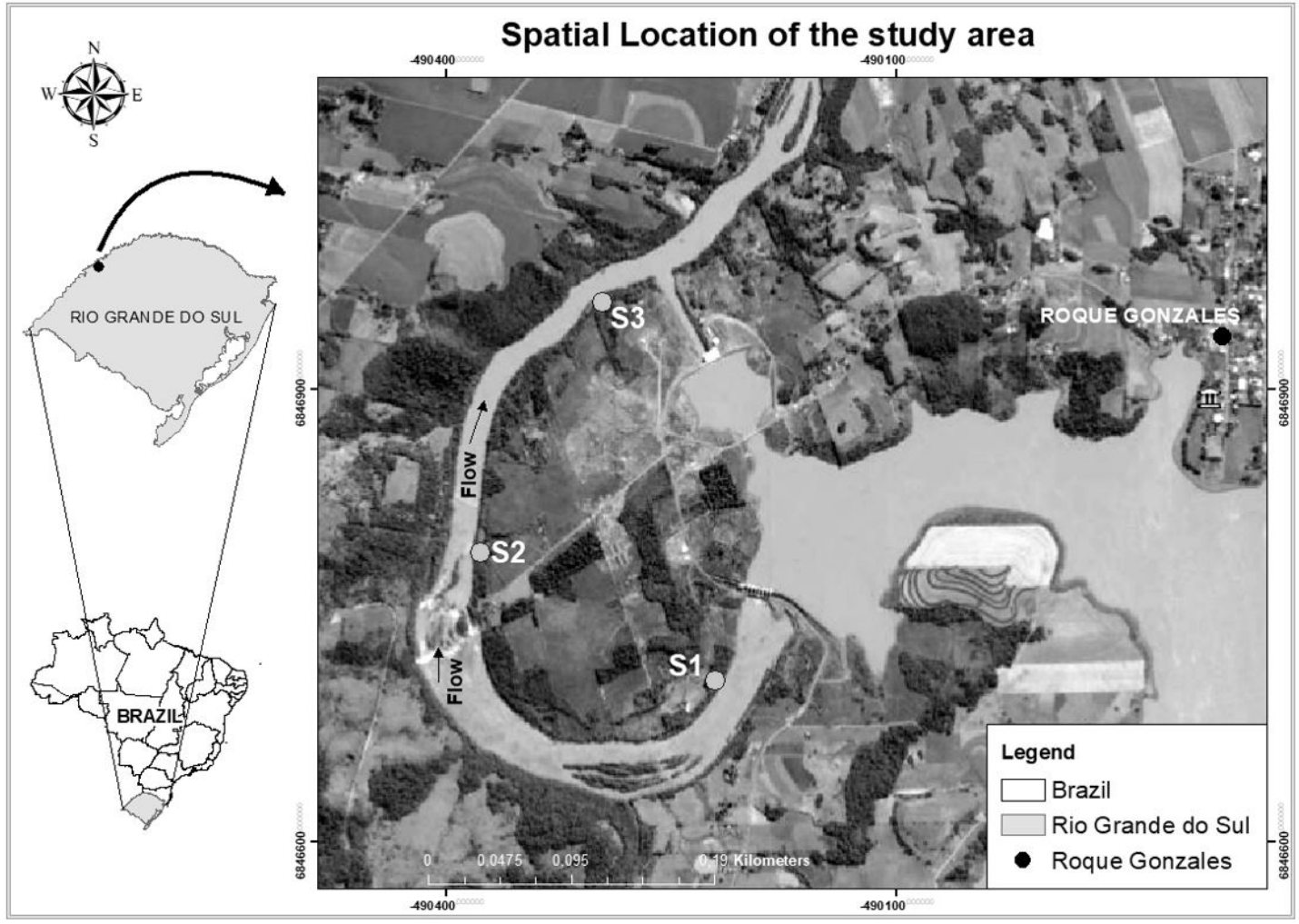

Figure 1. Spatial location of the study area and respective sample areas. 
$\mathrm{C}_{\mathrm{est}}=\left[\left(\frac{\mathrm{Q}}{0.095}\right)^{\frac{1}{1.534}}+57.62064\right]$

Where: $\mathrm{C}_{\text {est }}=$ estimated value of the dimension $(\mathrm{cm})$; $\mathrm{Q}=$ Flow $\left(\mathrm{m}^{3} / \mathrm{s}\right)$.

After the adjustments, the maximum levels of the flows in the RFS and their respective projected altimetric heights on the slopes of each area were estimated. The locating process of these sample units (SUs) involved systematic sampling by level intervals, which were demarcated in the field with the aid of a metric scale, a hose level and navigation GPS, with the altitudes of each SU then defined according to the estimated flow and flood characteristics.

\subsection{Floristic survey}

The points method adapted from Vieira \& Pessoa (2001) was used for the vegetative analysis. Five SUs in each sample area were divided into 50 -by-50 cm linear dimensions from " $A$ " to " $E$ " along the level curve and a length of $4.5 \mathrm{~m}$, forming a network of 50 sample points per sample (10 sampling points per SA) and arranged in grid format, as according to Frizzo \& Porto (2004). It should be noted that this methodology was used in order to not cause major disturbances in the environment, as well as to identify the small variations existing at the SU level, with the last level (dimension 5) representing a control for each sample, meaning not flooded.

The floristic survey of the herbaceous, shrub and liana strata, herein called life form analysis, was carried out at the species level using specialized literature, herbarium consultations and expert consultation, when necessary. The species classification followed the nomenclature proposed by Sobral et al. (2006), being classified by scientific nomenclature and by family.

The floristic comparison between the forest sections was carried out by elaborating a presence-and-absence matrix of the species, from which a dendrogram of similarity was constructed between all the sample areas and respective SU's, with all the species found according to the implemented methodology. The Jaccard similarity index was used according to Brower \& Zar (1984) for elaborating the dendrogram, along with the Unweighted Pair Group Method with Arithmetic Mean (UPGMA).

\subsection{Edaphic analysis}

The soil samples were randomly collected in each SU with the aid of an auger in the 0 to $20 \mathrm{~cm}$ layer, collecting three single samples per level, forming one composed sample per level for each sample area. The samples were submitted to chemical and physical analysis in the laboratory of the Soils Department of the Rural Sciences Center - UFSM, with several parameters being analyzed such as: clay content, $\mathrm{pH}-\mathrm{H}_{2} \mathrm{O}, \mathrm{SMP}$ index, Al Sat., Bases Sat., Clay, P, K, OM, Al, Ca, Mg, $\mathrm{P}, \mathrm{Cu}, \mathrm{Zn}, \mathrm{B}, \mathrm{S}$ and CEC pH7.

Interpretations of the chemical analysis reports were performed based on the Fertilization and Liming Manual for the states of Rio Grande do Sul and Santa Catarina (Tedesco et al., 2004). Statistical analysis of the data was performed by software R (R Core Team, 2016) through the Vegan library (Oksanen et al., 2016).

The canonical correspondence analysis (CCA) was used for the analysis and relation to the environmental variables, herein defined as the chemical variations of the soil. This allowed an analysis of the direct order of gradients and explained the species distribution in relation to the environmental variables, with the significance level assessed by the Monte Carlo permutation test (Braak \& Prentice, 1988).

\section{RESULTS}

According to the floristic survey carried out in the study area (as presented in Table 1), 30 species and 20 distinct botanical families were identified, and these were classified as a function of the altimetric/flood (SU) levels in the section slope and sample areas.

According to Table 1 and in view of the sample evaluation, all sample areas showed species presence of the Boraginaceae, Euphorbiaceae, Fabaceae, Myrtaceae and Urticaceae families. In addition, only one botanical family (Euphorbiaceae) was verified when the nearest water levels (Wl and level1) of all sample areas were evaluated in the most unstable and saturated conditions of the study area.

According to Table 2, which followed the classification proposed by Tedesco et al. (2004), it is observed that Cation Exchange Capacity (CEC-pH7) and the $\mathrm{Cu}$ and $\mathrm{Zn}$ micronutrients were maintained at high concentrations in all the SUs of each sample 
Table 1. Floristic/Phytosociological survey performed in the study area.

\begin{tabular}{|c|c|c|c|}
\hline SAMPLE & LEVEL & SPECIES & FAMILY \\
\hline \multirow{39}{*}{ S1 } & \multirow{3}{*}{ Wl } & Eugenia uniflora L. & Myrtaceae \\
\hline & & Actinostemon concolor (Spreng.) Müll.Arg. & Euphorbiaceae \\
\hline & & Terminalia australis Cambess. & Combretaceae \\
\hline & \multirow{8}{*}{ level1 } & Peplonia axillaris Fontella \& Rapini & Apocynaceae \\
\hline & & Actinostemon concolor (Spreng.) Müll.Arg. & Euphorbiaceae \\
\hline & & Eugenia uniflora L. & Myrtaceae \\
\hline & & Parapiptadenia rigida (Benth.) Brenan & Fabaceae \\
\hline & & Sebastiania schottiana (Müll.Arg.) Müll.Arg. & Euphorbiaceae \\
\hline & & Ruellia angustiflora (Ness) Lindau ex Rambo & Acanthaceae \\
\hline & & Terminalia australis Cambess. & Combretaceae \\
\hline & & Cordia salicifolia Cham. & Boraginaceae \\
\hline & \multirow{7}{*}{ level2 } & Eugenia uniflora L. & Myrtaceae \\
\hline & & Actinostemon concolor (Spreng.) Müll.Arg. & Euphorbiaceae \\
\hline & & Adenocalymma dusenii Kraenzl. & Bignoniaceae \\
\hline & & Sebastiania schottiana (Müll.Arg.) Müll.Arg. & Euphorbiaceae \\
\hline & & Ruellia angustiflora (Ness) Lindau ex Rambo & Acanthaceae \\
\hline & & Terminalia australis Cambess. & Combretaceae \\
\hline & & Cordia salicifolia Cham. & Boraginaceae \\
\hline & \multirow{6}{*}{ level3 } & Eugenia uniflora L. & Myrtaceae \\
\hline & & Actinostemon concolor (Spreng.) Müll.Arg. & Euphorbiaceae \\
\hline & & Parapiptadenia rigida (Benth.) Brenan & Fabaceae \\
\hline & & Terminalia australis Cambess. & Combretaceae \\
\hline & & Ruellia angustiflora (Ness) Lindau ex Rambo & Acanthaceae \\
\hline & & Peplonia axillaris Fontella \& Rapini & Apocynaceae \\
\hline & \multirow{7}{*}{ level4 } & Ruellia angustiflora (Ness) Lindau ex Rambo & Acanthaceae \\
\hline & & Actinostemon concolor (Spreng.) Müll.Arg. & Euphorbiaceae \\
\hline & & Cordia salicifolia Cham. & Boraginaceae \\
\hline & & Terminalia australis Cambess. & Combretaceae \\
\hline & & Bromus catharticus Vahl. & Poaceae \\
\hline & & Pilea microphylla Linn. & Urticaceae \\
\hline & & Eugenia uniflora L. & Myrtaceae \\
\hline & \multirow{8}{*}{ level5 } & Plagiothecium curvifolium Schlieph. ex Limpr. & Plagiotheciaceae \\
\hline & & Terminalia australis Cambess. & Combretaceae \\
\hline & & Actinostemon concolor (Spreng.) Müll.Arg. & Euphorbiaceae \\
\hline & & Pilea microphylla Linn. & Urticaceae \\
\hline & & Ruellia angustiflora (Ness) Lindau ex Rambo & Acanthaceae \\
\hline & & Eugenia uniflora L. & Myrtaceae \\
\hline & & Sebastiania schottiana (Müll.Arg.) Müll.Arg. & Euphorbiaceae \\
\hline & & Adenocalymma dusenii Kraenzl. & Bignoniaceae \\
\hline \multirow{13}{*}{ S2 } & \multirow{6}{*}{ Wl } & Bromus catharticus Vahl. & Poaceae \\
\hline & & Cordia trichotoma (Vell.) Arrab. ex Steud. & Boraginaceae \\
\hline & & Sebastiania commersoniana (Baill.) L.B. Sm. \& Downs & Euphorbiaceae \\
\hline & & Trema micrantha (L.) Blume & Cannabaceae \\
\hline & & Sebastiania schottiana (Müll.Arg.) Müll.Arg. & Euphorbiaceae \\
\hline & & Solanum paranense Dusén. & Solanaceae \\
\hline & \multirow{7}{*}{ level1 } & Cordia trichotoma (Vell.) Arrab. ex Steud. & Boraginaceae \\
\hline & & Sebastiania commersoniana (Baill.) L.B. Sm. \& Downs & Euphorbiaceae \\
\hline & & Eugenia pyriformis Cambess. & Myrtaceae \\
\hline & & Brachiaria plantaginea (Link) Hitchc. & Poaceae \\
\hline & & Chrysophyllum marginatum (Hook. \& Arn.) Radlk. & Sapotaceae \\
\hline & & Inga vera Willd. & Fabaceae \\
\hline & & Solanum paranense Dusén. & Solanaceae \\
\hline
\end{tabular}

$\mathrm{Wl}=$ Water level 
Table 1. Continued...

\section{SAMPLE LEVEL}

SPECIES

FAMILY

Pleurozium schreberi (Willd. ex Brid) Mitt.

Hylocomiaceae

Ageratum conyzoides (L.) L.

Coutarea hexandra (Jacq.) K. Schum.

level2 Chrysophyllum marginatum (Hook. \& Arn.) Radlk.

Asteraceae

Rubiaceae

Sapotaceae

Inga vera Willd.

Fabaceae

Serjania laruotteana Cambess.

Sapindaceae

Mikania cordifolia (L.f.) Willd.

Asteraceae

Pleurozium schreberi (Willd. ex Brid) Mitt.

Hylocomiaceae

Inga vera Willd.

Fabaceae

Mikania cordifolia (L.f.) Willd.

Brachiaria plantaginea (Link) Hitchc.

Asteraceae

Terminalia australis Cambess.

Poaceae

Combretaceae

level3 Serjania laruotteana Cambess.

Sapindaceae

Coutarea hexandra (Jacq.) K. Schum.

Plagiothecium curvifolium Schlieph. ex Limpr.

Rubiaceae

Sebastiania commersoniana (Baill.) L.B. Sm. \& Downs

Plagiotheciaceae

Euphorbiaceae

Chrysophyllum marginatum (Hook. \& Arn.) Radlk.

S2

Cordia salicifolia Cham.

Sapotaceae

Pleurozium schreberi (Willd. ex Brid) Mitt.

Pilea microphylla Linn.

Eugenia involucrata DC.

Plagiothecium curvifolium Schlieph. ex Limpr.

Boraginaceae

Hylocomiaceae

Urticaceae

Myrtaceae

Coutarea hexandra (Jacq.) K. Schum.

Plagiotheciaceae

level4 Cordia trichotoma (Vell.) Arrab. ex Steud.

Rubiaceae

Serjania laruotteana Cambess.

Cordia salicifolia Cham.

Bromus catharticus Vahl.

Eugenia uniflora L.

Eugenia involucrata DC.

Plagiothecium curvifolium Schlieph. ex Limpr.

Boraginaceae

Sapindaceae

Boraginaceae

Poaceae

Myrtaceae

Myrtaceae

Plagiotheciaceae

Pilea microphylla Linn.

Urticaceae

level5 Cordia trichotoma (Vell.) Arrab. ex Steud.

Chrysophyllum marginatum (Hook. \& Arn.) Radlk.

Boraginaceae

Sapotaceae

Actinostemon concolor (Spreng.) Müll.Arg.

Bromus catharticus Vahl.

Inga vera Willd.

Amphilophium crucigerum (L.) L.G.Lohmann.

Euphorbiaceae

Poaceae

Fabaceae

Coutarea hexandra (Jacq.) K. Schum.

Bignoniaceae

Rubiaceae

Wl Cordia trichotoma (Vell.) Arrab. ex Steud.

Boraginaceae

Actinostemon concolor (Spreng.) Müll.Arg.

Euphorbiaceae

Serjania laruotteana Cambess.

Sapindaceae

Amphilophium crucigerum (L.) L.G.Lohmann.

Bignoniaceae

Coutarea hexandra (Jacq.) K. Schum.

Rubiaceae

Cordia trichotoma (Vell.) Arrab. ex Steud.

Boraginaceae

Inga vera Willd.

Fabaceae

Adenocalymma dusenii Kraenzl.

Actinostemon concolor (Spreng.) Müll.Arg.

Bignoniaceae

Coutarea hexandra (Jacq.) K. Schum.

Euphorbiaceae

Rubiaceae

Eugenia uniflora L.

Myrtaceae

level2 Cordia trichotoma (Vell.) Arrab. ex Steud.

Boraginaceae

Inga vera Willd.

Fabaceae

$\mathrm{Wl}=$ Water level. 
Table 1. Continued...

\begin{tabular}{|c|c|c|c|}
\hline SAMPLE & LEVEL & SPECIES & FAMILY \\
\hline \multirow{14}{*}{ S3 } & \multirow{5}{*}{ level3 } & Amphilophium crucigerum (L.) L.G.Lohmann. & Bignoniaceae \\
\hline & & Actinostemon concolor (Spreng.) Müll.Arg. & Euphorbiaceae \\
\hline & & Coutarea hexandra (Jacq.) K. Schum. & Rubiaceae \\
\hline & & Eugenia involucrata DC. & Myrtaceae \\
\hline & & Pilea microphylla Linn. & Urticaceae \\
\hline & \multirow{4}{*}{ level4 } & Coutarea hexandra (Jacq.) K. Schum. & Rubiaceae \\
\hline & & Amphilophium crucigerum (L.) L.G.Lohmann. & Bignoniaceae \\
\hline & & Actinostemon concolor (Spreng.) Müll.Arg. & Euphorbiaceae \\
\hline & & Ageratum conyzoides (L.) L. & Asteraceae \\
\hline & \multirow{5}{*}{ level5 } & Marchantia paleacea Bertol. & Marchantiaceae \\
\hline & & Peplonia axillaris (Vell.) Fontella \& Rapini & Apocynaceae \\
\hline & & Actinostemon concolor (Spreng.) Müll.Arg. & Euphorbiaceae \\
\hline & & Sorocea bonplandii (Baill.) W.C. Burger, Lanjouw \& Boer & Moraceae \\
\hline & & Plinia rivularis (Cambess.) Rotman & Myrtaceae \\
\hline
\end{tabular}

$\mathrm{Wl}=$ Water level.

Table 2. Chemical characteristics of the soil samples (layer 0-20 cm) collected in 3 reduced flow section (RFS) SUs of the HPP, Passo São João, Rio Grande do Sul.

\begin{tabular}{|c|c|c|c|c|c|c|c|c|c|c|c|c|c|c|c|c|}
\hline \multirow[t]{2}{*}{$\begin{array}{c}\text { Sample } \\
\text { Level }\end{array}$} & \multirow{2}{*}{$\begin{array}{l}0 \\
\tilde{D}^{N} \\
\underline{\underline{z}}\end{array}$} & లే & $\sum_{\Sigma}^{\infty}$ & Z & ঠ্ঠু & $\frac{\dot{\mathscr{J}}}{4}$ & 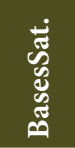 & \multirow{2}{*}{ 象 } & క & 空 & \multirow{2}{*}{$\frac{\infty}{\mathrm{mg} / \mathrm{dm}^{3}}$} & \pm & 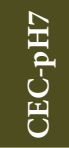 & 3 & งี & $\infty$ \\
\hline & & \multicolumn{4}{|c|}{$---\mathrm{cmol}_{\mathrm{c}} / \mathrm{dm}^{3}---$} & \multicolumn{2}{|c|}{---(\%)--- } & & \multicolumn{2}{|c|}{--(\%)-- } & & \multicolumn{2}{|c|}{$\mathrm{cmol} / \mathrm{dm}^{3}$} & \multicolumn{3}{|c|}{$--\mathrm{mg} / \mathrm{dm}^{3}--$} \\
\hline S1L1 & 5.4 & 14.9 & 8.5 & 0.2 & 23.9 & 0.8 & 87 & 6.2 & 0.7 & 32 & 13 & 92 & 27.2 & 14.8 & 4.4 & 0.2 \\
\hline S1L2 & 5.4 & 15.9 & 9.1 & 0.1 & 25.3 & 0.4 & 86.5 & 6.1 & 1 & 30 & 8.3 & 04 & 29.1 & 13.1 & 4.6 & 0.1 \\
\hline S1L3 & 5.4 & 13.6 & 7.8 & 0.1 & 21.7 & 0.5 & 84.5 & 6.1 & 1.2 & 31 & 7 & 68 & 25.5 & 13.4 & 3.8 & 0.2 \\
\hline S1L4 & 5 & 11.7 & 7.2 & 0.1 & 19.2 & 0.5 & 75.4 & 5.7 & 2.1 & 30 & 13 & 72 & 25.3 & 14.4 & 6.4 & 0.2 \\
\hline S1L5 & 4.9 & 11.5 & 7.4 & 0.3 & 19.3 & 1.6 & 71.2 & 5.5 & 1.9 & 31 & 13 & 72 & 26.7 & 13.3 & 5.4 & 0.2 \\
\hline S2L1 & 5.5 & 11.9 & 7.4 & 0 & 19.4 & 0 & 88.7 & 6.5 & 0.9 & 24 & 8 & 48 & 21.9 & 11.5 & 5.3 & 0.2 \\
\hline S2L2 & 5.4 & 9.8 & 5.9 & 0.1 & 15.9 & 0.6 & 81.6 & 6.2 & 1 & 21 & 8.1 & 32 & 19.3 & 11.5 & 5.1 & 0.1 \\
\hline S2L3 & 5.5 & 10.8 & 7.1 & 0 & 18.1 & 0 & 82.2 & 6.1 & 1.6 & 25 & 14 & 60 & 22 & 12 & 4.6 & 0.1 \\
\hline S2L4 & 5.1 & 9.5 & 6.7 & 0.3 & 16.7 & 1.8 & 77 & 5.9 & 1.9 & 25 & 17 & 68 & 21.3 & 11 & 3.9 & 0.4 \\
\hline S2L5 & 4.7 & 6.7 & 6 & 1 & 13.9 & 7.2 & 56.9 & 5.3 & 2.3 & 24 & 17 & 64 & 22.6 & 11.2 & 3.7 & 0.1 \\
\hline S3L1 & 5.5 & 15.6 & 8.7 & 0 & 24.5 & 0 & 84.6 & 6 & 2.2 & 31 & 16 & 40 & 28.9 & 18 & 8.6 & 0.1 \\
\hline S3L2 & 5.5 & 15.6 & 8.4 & 0 & 24.2 & 0 & 84.5 & 6 & 2.2 & 31 & 11 & 44 & 28.6 & 17.9 & 8.8 & 0.1 \\
\hline S3L3 & 5.5 & 15.5 & 6.8 & 0 & 22.4 & 0 & 80.2 & 5.8 & 2.4 & 34 & 15 & 28 & 27.9 & 18.5 & 8.7 & 0.1 \\
\hline S3L4 & 5.6 & 16.9 & 8.1 & 0 & 25.1 & 0 & 86.6 & 6.1 & 2.2 & 31 & 15 & 40 & 29 & 17.6 & 9 & 0.1 \\
\hline S3L5 & 5.7 & 18.3 & 9.2 & 0 & 27.6 & 0 & 87.7 & 6.1 & 2.6 & 30 & 16 & 44 & 31.5 & 16.6 & 9.6 & 0.1 \\
\hline
\end{tabular}

area (mean of $21.14 \mathrm{cmolc} / \mathrm{dm}^{3}, 14.32 \mathrm{mg} / \mathrm{dm}^{3}$ and $6.12 \mathrm{mg} / \mathrm{dm}^{3}$, respectively), with B concentration found being classified as average in most levels (average of $0.11 \mathrm{mg} / \mathrm{dm}^{3}$ ), with the exception of level 4 in sample area 2 (S2), which presented high concentrations of this element $\left(0.4 \mathrm{mg} / \mathrm{dm}^{3}\right)$. For the analyzed macronutrients ( $\mathrm{P}, \mathrm{K}, \mathrm{Ca}, \mathrm{Mg}$ and $\mathrm{S}$ ), they presented mean concentrations of: $2.8 \mathrm{mg} / \mathrm{dm}^{3}, 55.7 \mathrm{mg} / \mathrm{dm}^{3}$, $13.21 \mathrm{cmolc} / \mathrm{dm}^{3}, 7.62 \mathrm{cmolc} / \mathrm{dm}^{3}$, and $12.76 \mathrm{mg} / \mathrm{dm}^{3}$, thus being classified as very low and low for $\mathrm{P}$ and $\mathrm{K}$ respectively, and high for the other elements.

Regarding organic matter (OM), it presented a low concentration in the soil (mean of $1.7 \mathrm{~m} / \mathrm{v} \%$ ), which demonstrates the low availability of this element to the plants in the considered area. For $\mathrm{pH}$ in water, an average of 5.34 was found in its index, which ranks it as low $\mathrm{pH}$ or acid. Furhtermore, an average of $80.9 \%$ was verified regarding the percentage of base saturation in 
the analyzed samples, which classifies it as high on the base saturation index. However, this percentage drops to $0.89 \%$ for aluminum saturation, thus representing a very low index for this soil. The dendrogram shown in Figure 2 shows the floristic relationships generated by the grouping analysis of the species found in each sample area and SU by means of the group average (UPGMA), with the similarity then being greater than $50 \%$, as highlighted.

For the four highest similarity indexes (defined by the highlighted horizontal line), it was observed that these clusters were separated according to the location of the sample area and with the tendency to be in the nearest SUs. The subgroups presenting the greatest similarity among each other were: S1_L1 and S1_L3, S1_L4 and S1_L5, located in sample area 1; and S3_L1 and S3_W1, S3_L3 and S3_L4, located in sample area 3. This means that there was a high similarity between the plant species found at these levels and sites.

In these groupings, there was a greater affinity between the establishment/presence of certain species such as Parapiptadenia rigida and Peplonia axillaris; Marchantia paleaceae and Plinia rivularis; Sebastiania commersoniana and Solanum paranense; Eugenia involucrata and Pilea microphilla; and finally Coutarea hexandra and Inga vera.
The co-optic correlation coefficient (ccc) proposed by Sokal \& Rohlf (1962) presented a value of 0.88 , which indicates suitability in the grouping method used (Rohlf, 1970).

The ordering diagram of the plots in the first axis was generated by means of Canonical Correspondence Analysis (CCA) (Figure 3). CCA shows the division into groups with positive and negative eigenvalues, allied to the axes being sample areas (S1, S2 and S3) and their respective SUs with the floristic information and soil chemical characteristics (environmental variables) for each site. Eigenvalues of 0.84 and 0.72 were found for the CCA 1 and CCA 2 axes, respectively, which represented a percentage explanation of $20.9 \%$ and $18 \%$ of the data variance for these axes and correlated variables.

With this analysis, one can observe a clear division of the sample area 1 (S1) in relation to the others. This area showed a strong correlation between the presence of certain plant species such as Parapiptadenia rigida, Sebastiania schottiana, Ruellia angustiflora and Terminalia australis, among others, with soils containing higher concentrations of $\mathrm{K}, \mathrm{Al}, \mathrm{Al}$ Sat. and clay content.

In addition, species such as Brachiaria plantaginea, Eugenia pyriformis, Sebastiania commersoniana and Solanum paranense presented a higher correlation with the environmental variables: Base Sat., SMP and

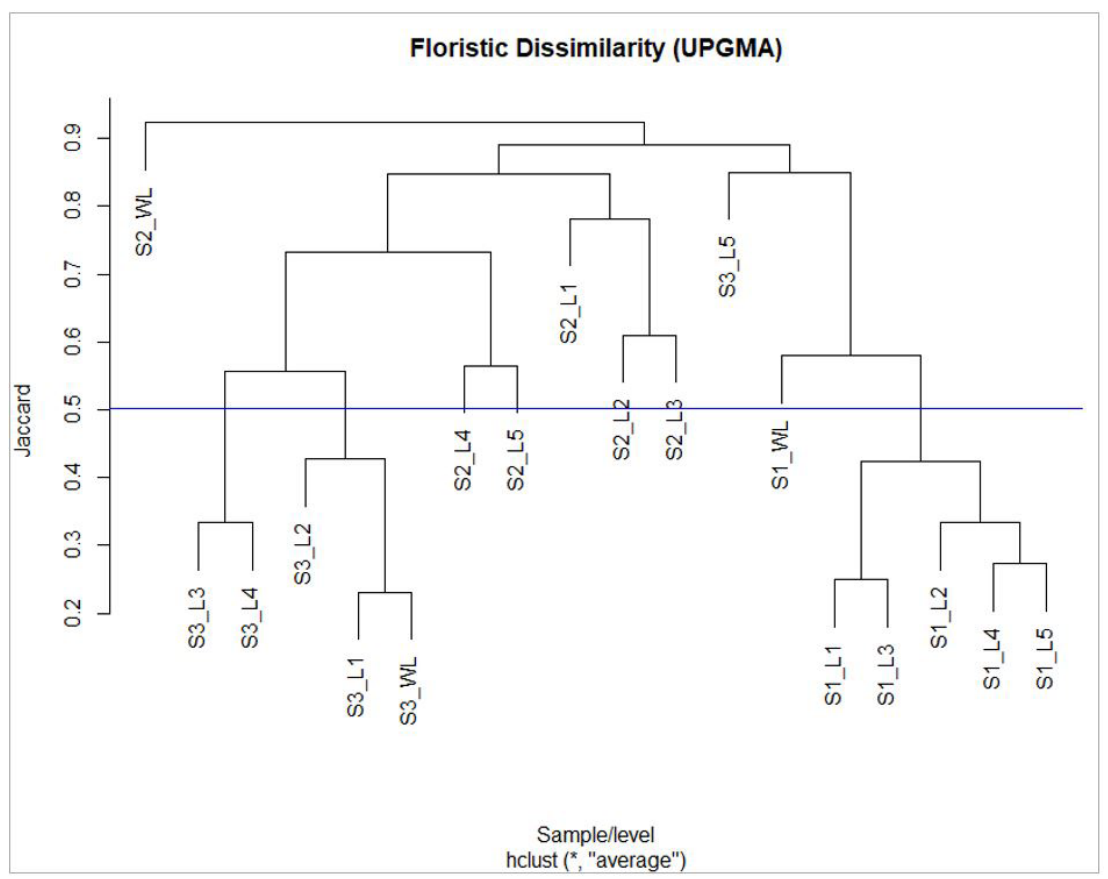

Figure 2. Dendrogram obtained through Jaccard index (UPGMA), based on the vegetal species found in study area. 


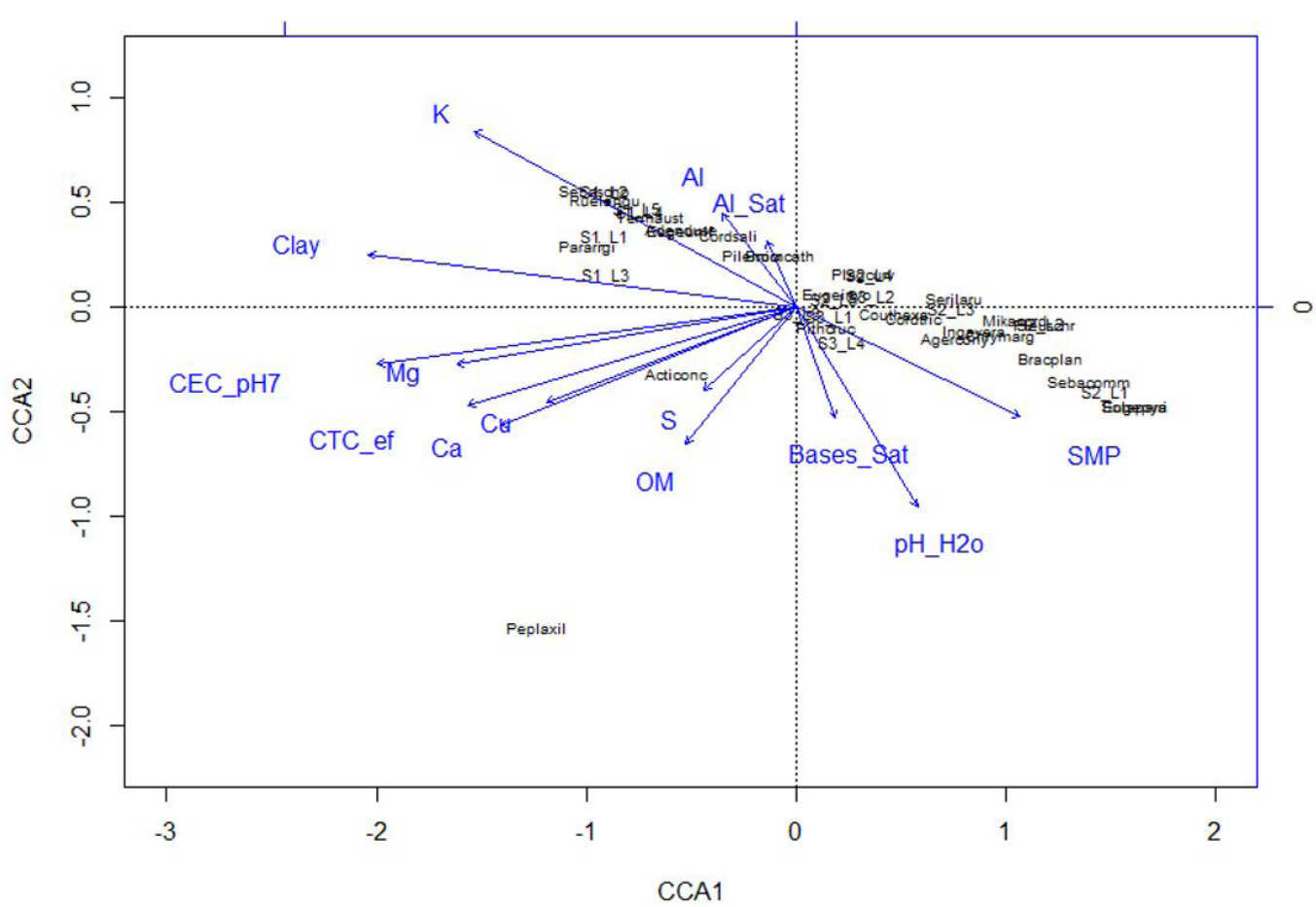

Figure 3. Canonical correspondence analysis (CCA) between the floristic variables and the environmental variables (chemical analysis of soil).

pH_H $\mathrm{H}_{2} \mathrm{O}$. In this sense, it is possible to confirm the tendency to establish certain botanical species and families according to soil characteristics, flooding (different levels) and spatial influence.

\section{DISCUSSION}

According to the survey of the plant species carried out in this work, species establishment tendencies in function of the environment characteristics may be verified. This can be clearly verified by the prominence/presence of certain botanical families in all sample areas, in which the Euphorbiaceae family represented by the species Actinostemon concolor, Sebastiania commersoniana and Sebastiania schottiana were highlighted in the nearer water levels (Wl and L1), thus demonstrating their evident adaptability to these conditions (higher humidity).

Similar results confirming the aptitude of this family to establish in these wetter environments were observed by Pinto et al. (2015) and Lacerda et al. (2007), both in riparian environments. In this context, it is worth mentioning the genus Sebastiania, which together with the studies of Souto (2012), Budke et al.
(2008) and Carvalho et al. (2016), demonstrate the adaptability of species included in this genus to these particular conditions.

Through analysis of the Figure 2 dendogram, it may be seen that there was a certain tendency in the division of similar groups by sample area; thus demonstrating an existing differentiation in the area and vegetation variation along the analyzed section, being strongly influenced by specific characteristics of each environment. By analyzing the sets of groups with the greatest similarity to each other as a function of the behavior in the flood levels of the region, we can observe a certain tendency of species grouping as a function of the proximity between the levels.

This shows the direct influence of the vegetation establishment due to the adaptability or conditions imposed by the environment, which in this case are strongly related to the water level variation (meaning the humidity in these ciliary environments), even at levels with little distance between one another. This behavior (the influence of water dynamics on vegetation establishment) was also observed in Campos et al. (2000) and Pinto et al. (2015) in a flood plain and spring areas, respectively. 
In this sense, it is possible to observe (via CCA) the ordering and grouping of plant species as a function of flood levels, spatial location along the RFS and soil chemical characteristics, which demonstrated the direct connection and complexity of these variables. In turn, such variables are responsible for the adaptation, establishment and permanence of these species under specifically induced or naturally occurring conditions, together with other factors and elements that act directly and indirectly in the environment.

Regarding the behavior of soil chemical elements in the analyzed areas and their availability to plants, this study confirms the results observed by Rodrigues et al. (2007). The authors show that an increase of soil acidity is inversely correlated with the levels of $\mathrm{Al}, \mathrm{K}, \mathrm{Ca}$ and $\mathrm{Mg}$. Thus, it can be verified that the establishment of some plant species such as Brachiaria plantaginea, Sebastiania commersoniana, Solanum paranense, among others, in environments with higher $\mathrm{pH}$, meaning with less availability of certain plant elements (Marschner, 1995), demonstrates the low nutritional requirement of these plants and their high adaptability under "restrictive" conditions imposed by this environment.

\section{CONCLUSIONS}

In this study, there was a tendency of greater similarity between plant species inserted in similar levels to each other, meaning with a direct influence of the RFS flow. The influence of the flow rate and soil characteristics have a direct influence on the existence and establishment of plant species according to their adaptation to the imposed conditions, even in small distances between them. In addition, a tendency in grouping by sample area was generally observed. The hypothesis for this behavior (variation along the stretch) is that the influence of specific conditions/factors in each area (meaning the flow rate characteristics in each section, terrain/slope, and soil chemical conditions, among others) acts directly in the establishment of plant species.

Moreover, the presence of certain botanical families in specific areas and levels was verified. For example in the case of the S3 sample area and level5 (S3L5), which was the only one that presented species of the Marchantiaceae and Moraceae families. Therefore there is a tendency of floristic differentiation in higher levels (with less influence of floods) that can be explained by possible less adaptability to the edaphic and humidity conditions of the environments closer to the river channel.

\section{SUBMISSION STATUS}

Received: 5 oct., 2017

Accepted: 26 apr., 2018

\section{CORRESPONDENCE TO}

\section{Diego Balestrin}

Departamento de Engenharia Florestal, Universidade Federal de Viçosa - UFV, Av. P.H. Rolfs, s/n, CEP 36570-000, Viçosa, MG, Brasil e-mail: diego.balest@gmail.com

\section{FINANCIAL SUPPORT}

Coordenação de Aperfeiçoamento de Pessoal de Nível Superior (CAPES).

\section{REFERENCES}

Bejarano MD, Jansson R, Nilsson C. The effects of hydropeaking on riverine plants: a review. Biological reviews of the Cambridge Philosophical Society 2018; 93(1): 658-673. PMid:28815925.

Braak CJFT, Prentice IC. A theory of gradient analysis. Advances in Ecological Research 1988; 18(1): 271-317. http://dx.doi.org/10.1016/S0065-2504(08)60183-X.

Brower JE, Zar JH. Field and laboratory methods for general ecology. Dubuque: WmC Publishers; 1984. 226 p. Budke JC, Jarenkow JA, Oliveira-Filho AT. Tree community features of two stands of riverine forest under different flooding regimes in Southern Brazil. Flora 2008; 203(2): 162-174. http://dx.doi.org/10.1016/j.flora.2007.03.001.

Campos JB, Romagnolo MB, Souza MC. Structure, composition and spatial distribution of tree species in a remnant of the semideciduous seasonal Alluvial Forest of the upper Paraná River Floodplain Curitiba. Brazilian Archives of Biology and Technology 2000; 43(2): 185-194. http://dx.doi.org/10.1590/S1516-89132000000200008.

Carvalho J, Galvão F, Rios RC, Velazco SJE. Monospecific dominance in an alluvial mixed ombrophyllous forest is Southern Brazil. Australian Journal of Basic and Applied Sciences 2016; 10(10): 38-44.

Carvalho J, Marques MCM, Roderjan CV, Barddal M, Sousa SGA. Relações entre a distribuição das espécies 
de diferentes estratos e as características do solo de uma floresta aluvial no Estado do Paraná, Brasil. Acta Botanica Brasílica 2009; 23(1): 1-9. http://dx.doi.org/10.1590/ S0102-33062009000100002.

Curcio GR, Galvão F, Bonnet A, Barddal ML, Dedecek RA. A floresta fluvial em dois compartimentos do rio Iguaçu, Paraná, Brasil. Floresta 2007; 37(2): 125-147. http://dx.doi.org/10.5380/rf.v37i2.8645.

Dalanesi PE, Oliveira AT Fo, Fontes MAL. Flora e estrutura do componente arbóreo da floresta do Parque Ecológico Quedas do Rio Bonito, Lavras, MG e correlações entre a distribuição das espécies e variáveis ambientais. Acta Botanica Brasílica 2004; 18(4): 737-757. http://dx.doi. org/10.1590/S0102-33062004000400005.

Dwivedi DK. A geographical approach: large dam and its geography relevance of present degrading scenario of river. International Journal of Applied and Universal Research 2016; 3: 35-40.

Fanelli G, Sanctis M, Gjeta E, Mullaj A, Attorre F. The vegetation of the Buna River Protected Landscape (Albania). Hacquetia 2015; 14(2): 129-174. http://dx.doi. org/10.1515/hacq-2015-0008.

Frizzo TC, Porto ML. Zoneamento da vegetação e sua relação com a ocorrência de estruturas mineralizadas na mina Volta Grande, Lavras do Sul. Porto Alegre: Iherringa; 2004.

Gonçalves I, Dias HCT, Martins SV, Souza AL. Fatores edáficos e as variações florísticas de um trecho de mata ciliar do Rio Gualaxo do Norte, Mariana, MG. Revista Árvore 2011; 35(6): 1235-1243. http://dx.doi.org/10.1590/ S0100-67622011000700010.

Ivanauskas NM, Rodrigues RR, Nave AG. Aspectos ecológicos de um trecho da floresta de brejo de Itatinga, SP: florística, fitossociologia e seletividade de espécies. Revista Brasileira de Botanica. Brazilian Journal of Botany 1997; 20(2): 139-153. http://dx.doi.org/10.1590/S010084041997000200005.

Jacomine PK. Solos sob matas ciliares. In: Filho RR, editor. Matas ciliares: conservação e recuperação. São Paulo: Edusp; 2009. p. 27-33.

Kotchetkoff-Henriques O, Joly CA, Bernacci LC. Relação entre solo e a composição florística de remanescente de vegetação natural no município de Ribeirão Preto, SP. Revista Brasileira de Botanica. Brazilian Journal of Botany 2005; 28(3): 541-562. http://dx.doi.org/10.1590/ S0100-84042005000300011.

Lacerda AV, Barbosa FM, Barbosa MRV. Estudo do componente arbustivo-arbóreo de matas ciliares na bacia do rio Taperoá, semi-árido paraibano: uma perspectiva para a sustentabilidade dos recursos naturais. Oecologia Brasiliensis 2007; 11(3): 331-340. http://dx.doi.org/10.4257/ oeco.2007.1103.03.

Lima JAS, Meneguelli NA, Gazel AB Fo, Pérez DV. Agrupamento de espécies arbóreas de uma floresta tropical por características de solo. Pesquisa Agropecuária
Brasileira 2003; 38(1): 109-116. http://dx.doi.org/10.1590/ S0100-204X2003000100015.

Marschner H. Mineral nutrition of higher plants. 2nd ed. London: Academic; 1995. 889 p.

New T, Xie Z. Impacts of large dams on riparian vegetation: applying global experience to the case of China's Three Gorges Dam. Biodiversity and Conservation 2008; 17(13): 3149-3163. http://dx.doi.org/10.1007/s10531-008-9416-2.

Oksanen J, Blanchet FG, Friendly M, Kindt R, Legendre P, McGlinn D, et al. Package 'vegan'. 2016 [cited 2016 Jul 26]. Available from: https://cran.r-project.org/web/ packages/vegan/vegan.pdf

Pereira IM, Botelho AS, Machado ELM, Silveira CJA. Tree species occurring on ariparian slope and correlations with soil variables in the upper Grande River, Minas Gerais, Brazil. Ciência Rural 2012; 42(12): 2192-2198. http:// dx.doi.org/10.1590/S0103-84782012005000092.

Pinto LVA, Davide AC, Botelho SA, Oliveira-Filho AT, Machado ELM. Distribution of tree and shrubs species along of the soil humidity gradient from punctual headwaters of the Santa Cruz stream watershed, Lavras/SE, Brazil. Cerne 2015; 11(3): 294-305.

Quadt V, Oitzinger G, Zsak K. Management of invasive tree species in the Donau-Auen National Park, Austria. In: Krumm F, Vítková L, editors. Introduced tree species in European forests: opportunities and challenges. Bonn: German Federal Ministry of Food and Agriculture; 2016. p. $404-411$.

R Core Team. R: A language and environment for statistical computing. Vienna: R Foundation for Statistical Computing; 2016 [cited 2016 Jul 26]. Available from: https://www.rproject.org/

Rodrigues LA, Carvalho DA, Oliveira-Filho AT, Curi N. Efeitos de solos e topografia sobre a distribuição de espécies arbóreas em um fragmento de floresta estacional semidecidual em Luminárias, MG. Revista Árvore 2007; 31(1): 25-35. http://dx.doi.org/10.1590/S010067622007000100004.

Rohlf FJ. Adaptive Hierarchical clustering schemes. Systematic Zoology 1970; 18(1): 58-82. http://dx.doi. org/10.2307/2412027.

Schneck F, Hepp LU. Fatores estruturadores de comunidades em riachos. Santa Maria: UFSM; 2010.

Silveira GL, Cruz RC, Cruz JC, Villela FS. Vazões ecológicas e remanescentes em rios alterados por barragens. Ciência \& Ambiente - Rios da América 2010; 41: 161-174.

Silveira GL. Relatório Final da Etapa 2 - Contrato AEM/S $n^{o}$ 1082/2004. Santa Maria: FEPAM; FATEC; 2006.

Sobral M, Jarenkow J, Brack P, Irgang B, Larocca J. Flora arbórea e arborescente do Rio Grande do Sul. São Carlos: RiMA; Novo Ambiente; 2006.

Sokal R, Rohlf F. The comparison of dendrograms by objective methods. Taxon 1962; 11(2): 33-40. http:// dx.doi.org/10.2307/1217208. 
Souto MAG. A conservationist approach on environmental diagnosis of ground use in the Iguatemi river basin, Mato Grosso do Sul State, Brazil. Acta Scientiarum. Biological Sciences; 2012; 34(3): 271-277. http://dx.doi.org/10.4025/ actascibiolsci.v34i3.9001.

Staes J, Willems P, Marbaix P, Vrebos D, Bal K, Meire P. Impact of climate change on river hydrology and ecology: a case study for interdisciplinary policy oriented research (SUDEM-CLI). Brussels: Federal Science Policy; 2010.112 p.

Streck EV, Kampf N, Dalmolin RSD, Klamt E, Nascimento PC, Schneider E, et al. Solos do Rio Grande do Sul. Porto Alegre: EMATER; 2008. 222 p.

Stromberg JC. Restoration of riparian vegetation in the south-western United States: importance of flow regimes and fluvial dynamism. Journal of Arid Environments 2001; 49(1): 17-34. http://dx.doi.org/10.1006/jare.2001.0833.

Tedesco MJ, Gianello C, Anghinoni I, Bissani CA, Camargo FA, Wietholter S. Manual de adubação e calagem para os Estados do Rio Grande do Sul e Santa Catarina. Porto Alegre: Sociedade Brasileira de Ciência do Solo; 2004.

Universidade Regional do Noroeste do estado do Rio Grande do Sul - Unijuí. Projeto de extensão: estudos ambientais. Ijuí: Unijuí; Porto Xavier: Coopercana; 2003.

Vieira CM, Pessoa SDV. Estrutura e composição florística do estrato herbáceo subarbustivo de um pasto abandonado na Reserva Biológica de Poço das Antas, município de Silva Jardim, RJ. Rodriguésia 2001; 52(80): 17-30. http:// dx.doi.org/10.1590/2175-78602001528002. 